https://nv.nltu.edu.ua

https://doi.org/10.15421/40280709

Article received 06.08.2018 p.

Article accepted 26.09.2018 p.

$@ \bowtie$ Correspondence author

УДК $630 * 811.2$

I. M. Sopushynskyy sopushynskyy@ukr.net

Р. Т. Максимчук' , І. М. Сопушинський', Я. М. Кополовець², В. Я. Заячук ${ }^{1}$

${ }^{I}$ Національний лісотехнічний університет України, м. Львів, Україна ${ }^{2}$ ДП "Перечинське лісове господарство", с. Сімер, Украӥна

\title{
ВНУТРІШНЬОВИДОВА ДИФЕРЕНЦІАЦІЯ ABIES ALBA MILL. ЗА СТРУКТУРОЮ ДЕРЕВИНИ
}

Вивчено особливості формування річного приросту ялиці білої з прямоволокнистою та хвилясто-завилькуватою структурою деревини. Розглянуто відмінності абсолютних значень ширини ранньої та пізньої деревини на 40 модельних деревах у шести деревостанах. Встановлено, що ширина ранньої деревини ялиці білої змінюється в середньому від 0,5 до 2,0 мм. Різке збільшення ширини ранньої деревини пов'язано з локальними екологічними чинниками. Абсолютні значення ширини пізньої деревини у прямоволокнистій структурі характеризуються меншими значеннями, ніж у екземплярів із хвилясто-завилькуватою структурою. Середні значення ширини річного кільця прямоволокнистої деревини ялиці білої змінюються в межах від 2,36 до 3,53 мм, а в дерев із хвилясто-завилькуватою деревиною - 3,98-5,74 мм. Встановлено істотну різницю в середніх значеннях ширини річного кільця, що властива для мінімальних та максимальних значень. Середня ширина річного кільця у хвилясто-завилькуватій деревині ялиці білої становить 5,74 мм, а ширина річного кільця змінюється від 1,05 до 11,57 мм. Однофакторним дисперсійним аналізом ширини річного кільця деревини ялиці білої в чотирьох деревостанах встановлено статистично значущу різницю між показниками макроструктури у прямоволокнистій та хвилясто-завилькуватій деревині. Рівень значущості між досліджуваними деревами з прямоволокнистою та хвилясто-завилькуватою деревиною становив $\mathrm{p}<0,05$.

Ключові слова: ялиця біла; прямоволокниста деревина; хвилясто-завилькувата деревина; річне кільце; рання деревина; пізня деревина.

Вступ. Ялиця біла (Abies alba Mill.) - одна з найважливіших деревних порід у гірських масивах Центральної Свропи (Parpan, 2000; de Vries, 2015). На ріст та розвиток деревної породи істотно впливають екологічні чинники, які визначають структурні особливості та якість деревини. Окрім цього, вид $є$ чутливим до змін навколишнього середовища і характеризується широким формовим різноманіттям (Zayachuk, 2014; Mauri et al., 2016; Zhang et al., 2018). Ялиця біла відрізняється морфологічними формами за габітусом крони, забарвленням та формою хвої, кольором кори тощо, що описано у вітчизняних та іноземних наукових працях (Schmidt, 2011; Zayachuk, 2014; Wasik et al., 2015).

Визначальним для виділення форми, як внутрішньовидової систематичної одиниці, є виділення груп особин виду, які не мають чітко відмежованого ареалу, однак відрізняються від типових представників того ж виду за певними біологічними (енергією росту), морфологічними (форма крони), фенологічними (ранні чи пізні за настанням окремих фенофаз), анатомічними та іншими особливостями (Zayachuk, 2014; Kobal et al., 2015). За ботанічною номенклатурою основними таксонами в систематиці вищих рослин є: царство $\rightarrow$ Regnum, відділ $\rightarrow$ Divisio, клас $\rightarrow$ Classis, порядок $\rightarrow$ Ordo, родина $\rightarrow$ Familia, рід $\rightarrow$ Genus, вид $\rightarrow$ Species, а поліморфні види поділяють на внутрішньовидові категорії: підвид $\rightarrow$ subspecies, різновид чи варіація $\rightarrow$ varietas, підрізновид $\rightarrow$ subvarietas, форма $\rightarrow$ forma, підформа $\rightarrow$ subforma (Zayachuk, 2014). Дві останні $€$ безареальними внутрішньовидовими категоріями і цінними для селективного відбору в лісовому господарстві та вирощування лісових деревних порід із заданими властивостями деревини через вегетативне розмноження.

Беручи до уваги те, що деревина займає більшу частину стовбура, то її структурні відмінності будуть здебільшого мати генетичну природу, що зумовлено ростом та розвитком меристематичної тканини - клітин камбію. Протягом вегетаційного періоду радіальний ріст деревної рослини зумовлений клітинами камбію, які зберігають свою ідентичність та формують назовні анатомічні елементи, тоді як дочірні клітини диференціюються у зрілі клітини деревини (Sopushynskyy, 2014). Отже, результатом росту та розвитку деревної рослини є анатомічні елементи ранньої та пізньої дере-

\section{Інформація про авторів:}

Максимчук Руслан Тарасович, аспірант, кафедра ботаніки, деревинознавства та недеревних ресурсів лісу. Email: r.maksymchuk@nltu.edu.ua

Сопушинський Іван Миколайович, д-р с.-г. наук, професор, кафедра ботаніки, деревинознавства та недеревних ресурсів лісу. Email: sopushynskyy@nltu.edu.ua

Кополовець Ярослав Михайлович, директор. Email: plh@ukr.net

Заячук Василь Яремович, канд. с.-г. наук, доцент, кафедра ботаніки, деревинознавства та недеревних ресурсів лісу. Email: Zayachuk_vsim@lviv.farlep.net

Цитування за ДСтУ: Максимчук Р. Т., Сопушинський І. М., Кополовець Я. М., Заячук В. Я. Внутрішньовидова диференціація аbies alba Mill. за структурою деревини. Науковий вісник НЛтУ України. 2018, т. 28, № 7. С. 44-48.

Citation APA: Maksymchuk, R. T., Sopushynskyy, I. M., Kopolovets, Ya. M., \& Zayachuk, V. Ya. (2018). Intraspecific differentiation of abies alba mill by wood structure. Scientific Bulletin of UNFU, 28(7), 44-48. https://doi.org/10.15421/40280709 
вини в межах річного кільця.

Метою роботи було вивчити структурні відмінності деревини ялиці білої форми "хвилясто-завилькувата" порівняно з прямоволокнистою.

Матеріал і методи дослідження. Для аналізу структурних відмінностей між прямоволокнистою та хвилясто-завилькуватою деревиною ялиці білої ми заклали шість пробних ділянок площею 0,5 га у вологій смереково-буковій суяличині $\left(\mathrm{C}_{3}-\mathrm{cm}-б к Я ц\right)$ ДП "Берегометське лісомисливське господарство" (табл. 1).

Табл. 1. Лісівничо-таксаційні показники деревостанів ялиці білої

\begin{tabular}{|c|c|c|c|c|c|c|c|c|}
\hline \multirow{2}{*}{$\begin{array}{l}\text { № } \\
3 / \Pi\end{array}$} & \multirow{2}{*}{$\begin{array}{l}\text { Кв./ } \\
\text { вид. }\end{array}$} & \multirow{2}{*}{$\begin{array}{c}\text { Склад дере- } \\
\text { востану }\end{array}$} & \multirow{2}{*}{\begin{tabular}{|c|} 
Висота \\
н.р.м., \\
м
\end{tabular}} & \multirow{2}{*}{$\begin{array}{l}\text { Вік, } \\
\text { років }\end{array}$} & \multirow{2}{*}{$\begin{array}{c}\text { Боні- } \\
\text { тет/пов } \\
\text { нота }\end{array}$} & \multicolumn{2}{|c|}{ Середня } & \multirow{2}{*}{$\begin{array}{l}\text { Запас } \\
\mathrm{m}^{3} \cdot r \mathrm{a}^{-}\end{array}$} \\
\hline & & & & & & $\begin{array}{l}\mathrm{H}, \\
M\end{array}$ & $\begin{array}{l}\mathrm{D}, \\
c \mathcal{M}\end{array}$ & \\
\hline \multicolumn{9}{|c|}{ Долішньо-Шепітське лісництво } \\
\hline 1 & $22 / 8$ & 5Яц2Ял3Бк & 750 & 107 & $\mathrm{I} / 0,80$ & 24 & 26 & 550 \\
\hline 3 & $24 / 9$ & 5Яц2ЯлЗБк & 865 & 107 & $\mathrm{I} / 0,70$ & 24 & 30 & 550 \\
\hline 6 & $24 / 10$ & 5Яц2ЯлЗБк & 922 & 117 & $\mathrm{I} / 0,70$ & 27 & 34 & 550 \\
\hline \multicolumn{9}{|c|}{ Лопушнянське лісництво } \\
\hline 2 & $27 / 20$ & 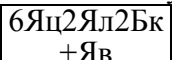 & 866 & 112 & $\mathrm{I} / 0,40$ & 30 & 34 & 345 \\
\hline 4 & $37 / 16$ & $\begin{array}{c}4 \text { 4Я ЗЯлЗБК } \\
+ \text { Яв }\end{array}$ & 1011 & 108 & $\mathrm{I} / 0,70$ & 31 & 45 & 349 \\
\hline 5 & $27 / 3$ & 7Яц1Ял2Бк & 1000 & 118 & $\mathrm{I} / 0,40$ & 29 & 47 & 387 \\
\hline
\end{tabular}

Примітка: $\mathrm{H}$ - середня висота; D - середній діаметр.
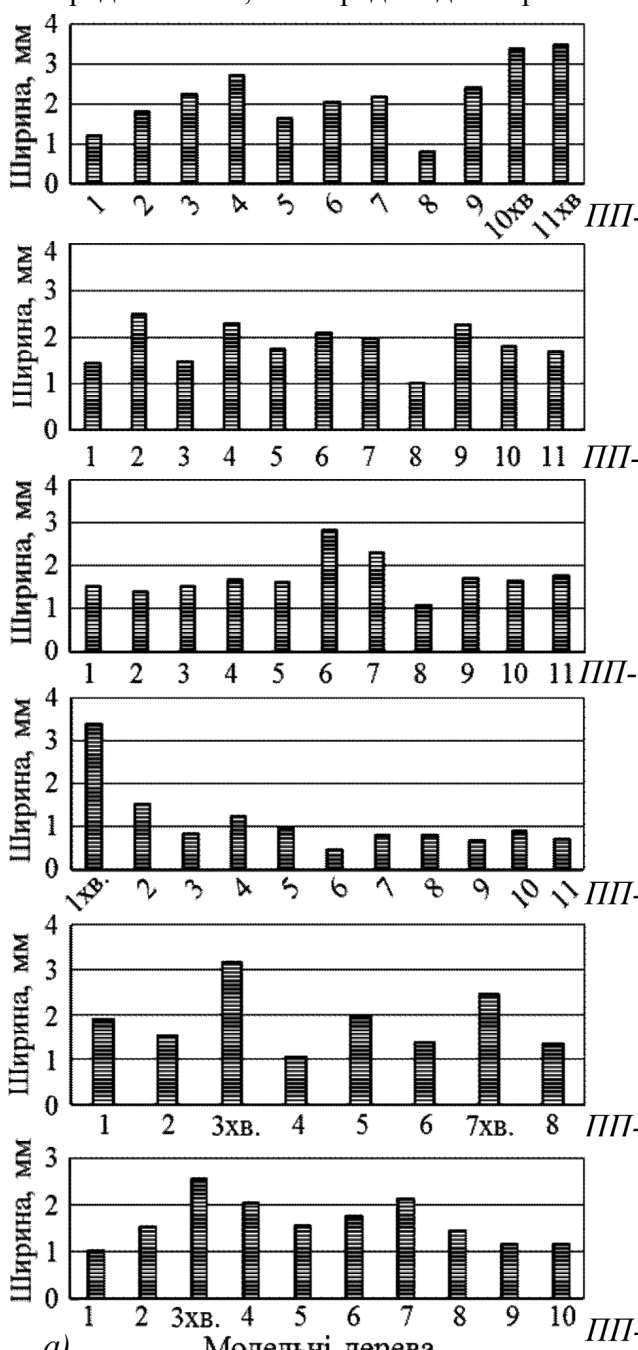

a)
Типи лісорослинних умов та типи лісу визначено за лісотипологічною методикою, яку запропонував проф. 3. Ю. Герушинський (Herushynskyy, 1996). Датування річних кілець виконували на обладнанні LinTab з використанням дендрохронологічної програми TSAP. Для статистичного опрацювання використано програмне забезпечення SPSS 13.0. Процедуру порівняння середніх значень показника макроструктури деревини проводили за допомогою однофакторного дисперсійного аналізу (One-way ANOVA). При цьому розкладами сумарну вибіркову дисперсію на складові, зумовлені незалежними чинниками. Незалежну змінну тестували за критеpiєм Шеффе (Scheffe), в основі якого лежить F-критерій. Відмінність однієї груп даних від іншої оцінювали за величиною значущості $p$ (ймовірність). При цьому використовували емпіричне правило, за яким значення $p$ більше від 0,05 , що свідчить про те, що рівень значущості є статистично важливим для груп зразків деревини за структурою деревини.

Результати дослідження та їх обговорення. Вплив екологічних чинників на структурні особливості формування річного приросту ялиці білої відображається через абсолютні значення ранньої та пізньої деревини, що наведено на рисунку.
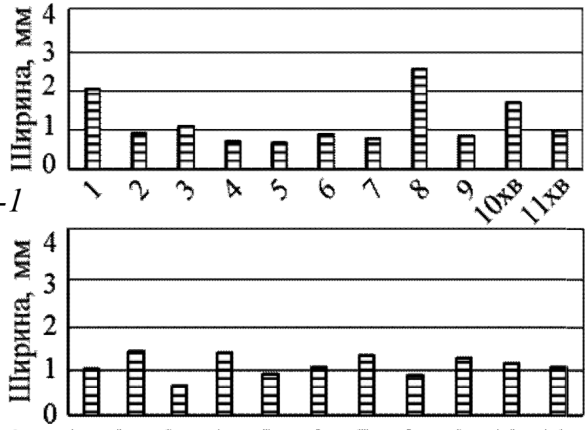
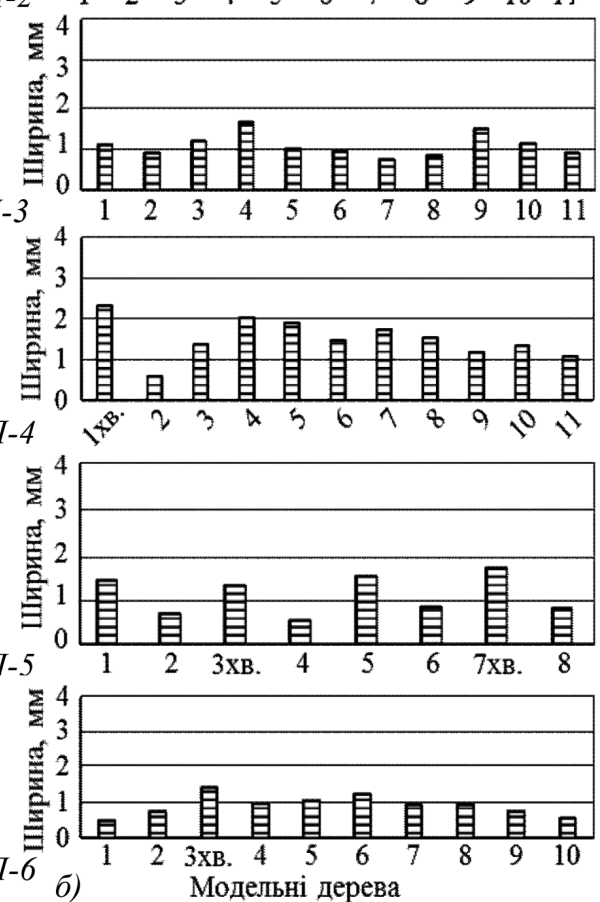

Рисунок. Ширина пізньої (а) та ранньої (б) деревини в модельних деревах ялиці білої з прямоволокнистою та хвилясто-завилькуватою структурою (хв.)

Як видно з цього рисунку, ширина ранньої деревини ялиці білої змінюється в середньому від 0,5 до 2,0 мм. Така варіабельність показника зумовлена чуттєвістю деревного виду до кліматичних змін на початку вегетаційного періоду, тобто в період формування ранньої деревини, що найчастіше проявляється в гірській екосис- 
темі. Різке збільшення ширини ранньої деревини в модельних деревах №1 та 8 на ПП-1 потрібно пов'язувати найімовірніше з локальними екологічними чинниками.

Абсолютні значення ширини пізньої деревини у прямоволокнистій деревині є меншими ніж 2,5 мм, а в екземплярів із хвилясто-завилькуватою структурою під номером 1 хв., 3 хв., 7 хв., 10 хв. та 11 хв. на ПП №1, 4 6 перевищують 2,5 мм (рисунок а). Такі відмінності показника макроструктури деревини значно визначають якісні характеристики стовбурної деревини ялиці білої.

Різницю між середніми значенням ширини пізньої та ранньої деревини в різних деревостанах пояснюємо мікрокліматичними чинниками управління розвитком провідної тканини для флоеми - температурний режим, а для ксилеми - водний. Однак аномальне збільшення абсолютних значень ширини пізньої деревини досліджуваних модельних дерев ялиці білої зі хвилясто-завилькуватою структурою деревини доцільно пов'язувати насамперед із генетичними змінами окремих біологічних особин.

Табл. 2. Статистичні показники середніх значень ширини річних кілець

\begin{tabular}{|c|c|c|c|c|c|}
\hline Модельні дерева & $\mathrm{N}_{\text {річ.кіл. }}$ & $\min$ & $\mathrm{M}^{ \pm \mathrm{m}}$ & $\max$ & $\mathrm{P}, \%$ \\
\hline \multicolumn{6}{|c|}{ ПП-1 } \\
\hline 1 & 77 & 0,62 & $3,27^{ \pm 0,1 T}$ & 8,02 & 5,3 \\
\hline 2 & 56 & 1,24 & $2,73^{ \pm 0,10}$ & 6,26 & 3,6 \\
\hline 3 & 59 & 0,51 & $3,34^{ \pm 0,18}$ & 6,94 & 5,5 \\
\hline 4 & 74 & 1,03 & $3,45^{ \pm 0,16}$ & 6,55 & 4,5 \\
\hline 5 & 68 & 0,25 & $2,36^{ \pm 0,21}$ & 5,69 & 8,7 \\
\hline 6 & 65 & 0,66 & $2,94^{ \pm 0,19}$ & 6,50 & 6,5 \\
\hline 7 & 75 & 0,51 & $2,98^{ \pm 0,19}$ & 6,71 & 6,4 \\
\hline 8 & 72 & 0,95 & $3,37^{ \pm 0,15}$ & 6,10 & 4,4 \\
\hline 9 & 61 & 1,36 & $3,25^{ \pm 0,21}$ & 6,70 & 6,6 \\
\hline 10 хв. & 61 & 2,89 & $5,11^{ \pm 0,23}$ & 11,03 & 4,5 \\
\hline $11 \mathrm{xB}$. & 60 & 2,56 & $4,48^{ \pm 0,16}$ & 7,51 & 3,6 \\
\hline \multicolumn{6}{|c|}{ ПП-4 } \\
\hline $1 \mathrm{XB}$. & 63 & 1,05 & $5,74^{ \pm 0,27}$ & 11,57 & 4,8 \\
\hline 2 & 104 & 0,47 & $2,11^{ \pm 0,07}$ & 4,07 & 3,4 \\
\hline 3 & 89 & 0,52 & $2,20^{ \pm 0,13}$ & 4,77 & 5,7 \\
\hline 4 & 77 & 0,77 & $3,25^{ \pm 0,17}$ & 7,64 & 5,3 \\
\hline 5 & 103 & 0,96 & $2,89^{ \pm 0,12}$ & 6,46 & 4,3 \\
\hline 6 & 114 & 0,24 & $1,91^{ \pm 0,10}$ & 4,49 & 5,2 \\
\hline 7 & 105 & 0,84 & $2,55^{ \pm 0,11}$ & 4,87 & 4,1 \\
\hline 8 & 96 & 1,00 & $2,32^{ \pm 0,08}$ & 4,30 & 3,4 \\
\hline 9 & 122 & 0,41 & $1,85^{ \pm 0,07}$ & 4,43 & 4,0 \\
\hline 10 & 105 & 0,53 & $2,23^{ \pm 0, \Pi 1}$ & 5,16 & 5,1 \\
\hline 11 & 86 & 0,55 & $1,77^{ \pm 0,09}$ & 3,97 & 5,0 \\
\hline \multicolumn{6}{|c|}{ ПП-5 } \\
\hline 1 & 67 & 0,74 & $3,39^{ \pm 0,14}$ & 6,83 & 4,2 \\
\hline 2 & 116 & 0,48 & $2,25^{ \pm 0,12}$ & 7,20 & 5,2 \\
\hline 3 хв. & 64 & 1,59 & $4,52^{ \pm 0,13}$ & 9,60 & 2,9 \\
\hline 4 & 94 & 0,12 & $1,59^{ \pm 0,08}$ & 3,01 & 4,9 \\
\hline 5 & 69 & 1,12 & $3,53^{ \pm 0,12}$ & 5,53 & 3,4 \\
\hline 6 & 118 & 0,11 & $2,24^{ \pm 0,14}$ & 7,74 & 6,3 \\
\hline 7 хв. & 63 & 1,95 & $4,25^{ \pm 0,18}$ & 7,97 & 4,2 \\
\hline 8 & 98 & 0,13 & $2,15^{ \pm 0,15}$ & 7,17 & 7,0 \\
\hline \multicolumn{6}{|c|}{ ПП-6 } \\
\hline 1 & 115 & 0,19 & $1,50^{ \pm 0,10}$ & 5,09 & 6,7 \\
\hline 2 & 80 & 0,77 & $2,28^{ \pm 0,12}$ & 5,19 & 5,3 \\
\hline 3 хв. & 67 & 0,91 & $3,98^{ \pm 0,21}$ & 9,69 & 5,2 \\
\hline 4 & 69 & 1,67 & $3,03^{ \pm 0,10}$ & 5,28 & 3,4 \\
\hline 5 & 97 & 0,72 & $2,61^{ \pm 0,13}$ & 6,31 & 5,0 \\
\hline 6 & 82 & 0,60 & $3,05^{ \pm 0,10}$ & 4,44 & 3,3 \\
\hline 7 & 78 & 1,08 & $3,07^{ \pm 0,12}$ & 5,14 & 4,0 \\
\hline 8 & 114 & 0,08 & $2,39^{ \pm 0,13}$ & 6,12 & 5,2 \\
\hline 9 & 111 & 0,07 & $1,92^{ \pm 0,16}$ & 7,09 & 8,4 \\
\hline 10 & 114 & 0,27 & $1,75^{ \pm 0,11}$ & 5,42 & 6,0 \\
\hline
\end{tabular}

Отже, розвиток відхилень у структуроутворенні деревини в лісорослинних умовах Українських Карпат необхідно пов'язувати не тільки зі структурою водної системи хвойних порід, яка $є$ дуже вразлива до різких несприятливих кліматичних та екологічних умов, а також iз генетичними особливостями, які зумовлюють внутрішньовидову диференціацію деревного виду. Зміна ширини ранньої деревини в річному кільці ялиці білої $\epsilon$ реакцією на несприятливі лісорослинні умови росту і не зумовлює вміст пізньої деревини. Найбільш динамічним показником у біологічному деревинознавстві, що реагує на зміну екологічних чинників та розкриває внутрішньовидову диференціацію деревних порід за структурою деревини, є величина річного приросту.

Внутрішньовидову диференціацію деревного виду чітко простежуємо через виявлення закономірностей формування величини річного приросту та його відхилення від середнього значення в межах одного деревостану (табл. 2). Цифрові дані цієї таблиці свідчать про те, що середні значення ширини річного кільця прямоволокнистої деревини ялиці білої на ПП-1 знаходяться в межах від 2,36 до 3,45 мм, а в дерев із хвилясто-завилькуватою деревиною - 4,48-5,11 мм.

Істотна різниця в середніх значеннях ширини річного кільця властива також для мінімальних та максимальних значень. Найбільша відмінність показника макроструктури характерна для ПП-4, де середня ширина річного кільця у хвилясто-завилькуватій деревині ялиці білої досягає 5,74 мм, а ширина річного кільця змінюється від 1,05 до 11,57 мм. Відхилення ширини річного кільця у прямоволокнистій та хвилясто-завилькуватій деревині притаманне для досліджуваних дерев на ПП-1, 4-6. Такі закономірності структурних перетворень, що виявлено у хвилясто-завилькуватій деревині ялиці білої, були зумовлені різкою зміною екологічних чинників протягом тривалого періоду, які спричинили порушення кореляції ростових процесів.

Отож, доцільно зазначити, що визначення макроструктурних показників деревини на ранніх стадіях розвитку лісових деревних порід створює можливість відбору найбільш перспективних особин із прогнозовано цінними властивостями деревини. Ці дослідження дають підстави говорити про селективний відбір дерев ялиці білої за енергією росту в конкретних лісорослинних умовах. 3 огляду на зазначене вище, важливим $\epsilon$ врахування спадкової мінливості досліджуваної форми під впливом чинників зовнішнього середовища. Мінливість ялиці білої з хвилясто-завилькуватою структурою деревини доцільно пов'язувати $з$ якісними та кількісними деревинознавчими ознаками. Останні оцінюють внаслідок вимірювання ширини річного кільця. Для аналізу структурних відмінностей деревини ялиці білої проведемо порівняння середніх значень показника макроструктури деревини за допомогою однофакторного дисперсійного аналізу (табл. 3).

Результати однофакторного дисперсійного аналізу ширини річного кільця деревини ялиці білої в чотирьох деревостанах свідчать про те, що існує статистично значуща різниця показника макроструктури у прямоволокнистій та хвилясто-завилькуватій деревині ялиці білої. Рівень значущості між деревами 3 прямоволокнистою та хвилясто-завилькуватою деревиною знаходиться в межах від 0,000 до 0,042, тобто $\mathrm{p}<0,05$. 
Табл. 3. Однофакторний дисперсійний аналіз ширини річного кільця ялиці білої із прямоволокнистою та хвилясто-завилькуватою (хв.) структурою

\begin{tabular}{|c|c|c|c|c|c|c|}
\hline \multirow{2}{*}{ Модельне дерево (I) } & \multirow{2}{*}{$\begin{array}{l}\text { Модельне } \\
\text { дерево (J) }\end{array}$} & \multirow{2}{*}{$\begin{array}{c}\text { Різниця середніх } \\
\text { (I-J) }\end{array}$} & \multirow{2}{*}{$\begin{array}{l}\text { Стандартна } \\
\text { помилка }\end{array}$} & \multirow{2}{*}{ Значущість, $p$} & \multicolumn{2}{|c|}{95 \% довірчий інтервал } \\
\hline & & & & & Нижня межа & Верхня межа \\
\hline \multicolumn{7}{|c|}{ ПП-1 } \\
\hline \multirow{10}{*}{$10 \mathrm{xB}}$. & 1 & $1,84338\left(^{*}\right)$ & 0,25600 & 0,000 & 0,7441 & 2,9426 \\
\hline & 2 & $2,37661(*)$ & 0,27640 & 0,000 & 1,1897 & 3,5635 \\
\hline & 3 & $1,77153(*)$ & 0,27271 & 0,000 & 0,6005 & 2,9426 \\
\hline & 4 & $1,66135(*)$ & 0,25828 & 0,000 & 0,5523 & 2,7704 \\
\hline & 5 & $2,74794(*)$ & 0,26338 & 0,000 & 1,6170 & 3,8789 \\
\hline & 6 & $2,16677(*)$ & 0,26624 & 0,000 & 1,0235 & 3,3100 \\
\hline & 7 & $2,13360(*)$ & 0,25750 & 0,000 & 1,0279 & 3,2393 \\
\hline & 8 & $1,73597(*)$ & 0,25990 & 0,000 & 0,6200 & 2,8520 \\
\hline & 9 & $1,85541(*)$ & 0,27043 & 0,000 & 0,6942 & 3,0167 \\
\hline & $11 \mathrm{xB}$. & 0,63383 & 0,27155 & 0,859 & $-0,5322$ & 1,7999 \\
\hline \multicolumn{7}{|c|}{ ПП-4 } \\
\hline \multirow{10}{*}{$1 \mathrm{xB}}$. & 2 & $3,63270\left(^{*}\right)$ & 0,18297 & 0,000 & 2,8479 & 4,4175 \\
\hline & 3 & $3,53422(*)$ & 0,18870 & 0,000 & 2,7249 & 4,3436 \\
\hline & 4 & $2,48515(*)$ & 0,19470 & 0,000 & 1,6501 & 3,3202 \\
\hline & 5 & $2,84856(*)$ & 0,18330 & 0,000 & 2,0623 & 3,6348 \\
\hline & 6 & $3,82992(*)$ & 0,17992 & 0,000 & 3,0582 & 4,6016 \\
\hline & 7 & $3,18905(*)$ & 0,18264 & 0,000 & 2,4057 & 3,9724 \\
\hline & 8 & $3,41519(*)$ & 0,18582 & 0,000 & 2,6182 & 4,2122 \\
\hline & 9 & $3,89323(*)$ & 0,17780 & 0,000 & 3,1306 & 4,6559 \\
\hline & 10 & $3,50590(*)$ & 0,18264 & 0,000 & 2,7225 & 4,2893 \\
\hline & 11 & $3,96695(*)$ & 0,19006 & 0,000 & 3,1518 & 4,7821 \\
\hline \multicolumn{7}{|c|}{ ПП-5 } \\
\hline \multirow{7}{*}{3 хв. } & 1 & $1,12881(*)$ & 0,22254 & 0,001 & 0,2913 & 1,9663 \\
\hline & 2 & $2,26595(*)$ & 0,19826 & 0,000 & 1,5199 & 3,0120 \\
\hline & 4 & $2,92723\left(^{*}\right)$ & 0,20634 & 0,000 & 2,1508 & 3,7037 \\
\hline & 5 & $0,98768(*)$ & 0,22096 & 0,006 & 0,1562 & 1,8192 \\
\hline & 6 & $2,28407(*)$ & 0,19766 & 0,000 & 1,5403 & 3,0279 \\
\hline & $7 \mathrm{XB}$. & 0,27159 & 0,22597 & 0,984 &,- 5788 & 1,1219 \\
\hline & 8 & $2,37000(*)$ & 0,20463 & 0,000 & 1,6000 & 3,1400 \\
\hline \multicolumn{7}{|c|}{ ПП-6 } \\
\hline \multirow{9}{*}{3 хв. } & 1 & $\left.2,478599^{*}\right)$ & 0,20021 & 0,000 & 1,6529 & 3,3043 \\
\hline & 2 & $1,70286(*)$ & 0,21573 & 0,000 & 0,8131 & 2,5926 \\
\hline & 4 & $0,95615\left(^{*}\right)$ & 0,22343 & 0,033 & 0,0346 & 1,8777 \\
\hline & 5 & $1,37616(*)$ & 0,20693 & 0,000 & 0,5227 & 2,2296 \\
\hline & 6 & $\left.0,934566^{*}\right)$ & 0,21453 & 0,026 & 0,0498 & 1,8193 \\
\hline & 7 & $0,91006(*)$ & 0,21698 & 0,042 & 0,0151 & 1,8050 \\
\hline & 8 & $1,59066(*)$ & 0,20053 & 0,000 & 0,7636 & 2,4177 \\
\hline & 9 & $2,06332(*)$ & 0,20153 & 0,000 & 1,2321 & 2,8945 \\
\hline & 10 & $2,23250(*)$ & 0,20053 & 0,000 & 1,4054 & 3,0596 \\
\hline
\end{tabular}

Примітка: * - за різниці середніх значень $\mathrm{p}<0,05$ - групу значень вважають самостійною.

Беручи до уваги отримані результати однофакторного дисперсійного аналізу ширини річного кільця 34 дерев ялиці білої із прямоволокнистою структурою деревини та 6 дерев із хвилясто-завилькуватою, доцільно виокремити форму ялиці білої "хвилясто-завилькувата".

Висновки. Результати дослідження внутрішньовидової диференціації ялиці білої в Українських Карпатах свідчать про значні структурні відмінності між прямоволокнистою та хвилясто-завилькуватою деревиною, а саме у формуванні ширини ранньої та пізньої деревини. Середні значення ширини річного кільця ялиці білої із прямоволокнистою деревиною характеризуються меншими значеннями і знаходяться в межах від 2,36 до 3,53 мм, а в дерев із хвилясто-завилькуватою деревиною - 3,98-5,74 мм. Однофакторний дисперсійний аналіз ширини річного кільця 40 дерев ялиці білої дав змогу виділити форму "хвилясто-завилькувату".

\section{Перелік використаних джерел}

de Vries, S. M. G., Alan, M., Bozzano, M., Burianek, V., Collin, E., Cottrell, J., Ivankovic, M., Kelleher, C. T., Koskela, J., Rotach, P., Vietto, L., \& Yrjänä, L. (2015). Pan-European strategy for genetic conservation of forest trees and establishment of a core network of dynamic conservation units. European Forest Genetic Resources Programme (EUFORGEN), Bioversity International, Rome, Italy. $\mathrm{xii}+40 \mathrm{p}$.
Herushynskyy, Z. Yu. (1996). Typolohiya lisiv Ukrainskych Karpat. Lviv: Piramida. [In Ukrainian].

Kobal, M., Grčman, H., Zupan, M., Levanič, T., Simončič, P., Kadunc, A., \& Hladnik, D. (2015). Influence of soil properties on silver fir (Abies alba Mill.) growth in the Dinaric Mountains. Forest Ecology and Management, 337, 77-87.

Mauri, A., de Rigo, D., \& Caudullo, G. (2016). Abies alba in Europe: distribution, habitat, usage and threats. In: San-Miguel-Ayanz, J., de Rigo, D., Caudullo, G., Houston Durrant, T., Mauri, A. (Eds.), European Atlas of Forest Tree Species. Publ. Off. EU, Luxembourg, pp. $\mathrm{e} 01493 \mathrm{~b}+$

Parpan, T. V. (2000). Biological and geographical features Abies alba Mill. in Central Europe and in Ukraine. Scientific Bulletin of UNFU, 10(3), 54-69. [In Ukrainian].

Schmidt, O. (2011). Waelder im Klimawandel - Weisstanne und Kuestentanne. Freising. LWF Wissen, 66. [In German].

Sopushynskyy, I. M. (2014). Intraspecific differentiation of sycamore (Acer pseudoplatanus L.), European beech (Fagus sylvatica L.) and Common ash (Fraxinus excelsior L.) by decorative wood. Lviv: UNFU. [In Ukrainian].

Wasik, R., Michalec, K., \& Barszcz, A. (2015). The variability of certain macrostructural features and the density of grand fir (Abies Grandis Lindl.) wood from selected stands in southern Poland. Drewno, $58(195)$

45-58. https://doi.org/10.12841/wood.1644-3985.118.04

Zayachuk, V. Ya. (2014). Dendrologiya. Textbook. Lviv: Spolom. [In Ukrainian]. 
Zhang, L., Jiang, Yu., Zhao, Sh., Jiao, L., \& Wen, Ya. (2018). Relationships between Tree Age and Climate Sensitivity of Radial Growth in Different Drought Conditions of Qilian Mountains,

Northwestern China. Forests, 9, https://doi.org/10.3390/f9030135

\author{
Р. Т. Максымчук', И. М. Сопушинский' ${ }^{1}$ Я. М. Кополовець ${ }^{2}$, В. Я. Заячук ${ }^{1}$ \\ ${ }^{1}$ Национальный лесотехнический университет Украины, г. Львов, Украина \\ ${ }^{2}$ ГП "Перечинское лесное хозяйство", ???с. Симер, Украина
}

\title{
ВНУТРИВИДОВАЯ ДИФФЕРЕНЦИАЦИЯ ABIES ALBA MILL. ПО СТРУКТУРЕ ДРЕВЕСИНЫ
}

Изучены особенности формирования годичного прироста пихты белой с прямоволокнистой и волнисто-свилеватой структурой древесины. Рассмотрены различия абсолютных значений ширины ранней и поздней древесины на 40 модельных деревьях в шести древостоях. Установлено, что ширина ранней древесины пихты белой меняется в среднем от 0,5 до 2,0 мм. Резкое увеличение ширины ранней древесины связано с локальными экологическими факторами. Абсолютные значения ширины поздней древесины с прямоволокнистой структурой характеризуются меньшими значениями чем в экземплярах с волнисто-свилеватой структурой. Средние значения ширины годичного кольца прямоволокнистой древесины пихты белой изменяются в пределах от 2,36 до 3,53 мм, а у деревьев с волнисто-свилеватой древесиной - 3,98-5,74 мм. Установлено существенную разницу в средних значениях ширины годичного кольца, которая присуща также для минимальных и максимальных значений. Средняя ширина годичного кольца в волнисто-свилеватой древесине пихты белой составляет 5,74 мм, а ширины годичного кольца меняется от 1,05 до 11,57 мм. Однофакторным дисперсионным анализом ширины годичного кольца древесины пихты белой в четырех древостоев установлено статистически значимую разницу между показателя макроструктуры в прямоволокнистой и волнисто-свилеватой древесине. Уровень значимости между исследуемыми деревьями с прямоволокнистою и волнисто-свилеватой составил $\mathrm{p}<0,05$.

Ключевые слова: пихта белая; прямоволокнистая древесина; волнисто-свилеватая древесина; годичное кольцо; ранняя и поздняя древесина.

\section{R. T. Maksymchuk1, I. M. Sopushynskyy', Ya. M. Kopolovets' ${ }^{2}$, V. Ya. Zayachuk1 \\ ${ }^{I}$ Ukrainian National Forestry University, Lviv, Ukraine \\ 2 State Enterprise "Perechyn Forestry", Simer, Ukraine}

\section{INTRASPECIFIC DIFFERENTIATION OF ABIES ALBA MILL BY WOOD STRUCTURE}

The authors specify the necessity to determine the form as an intraspecific systematic unit is to distinguish the allocation of groups of individuals of the tree species that do not have a clearly natural growing area, but they differ from the typical representatives of the same species for certain biological (growth energy), morphological (crown form), phenological, anatomical and other features. The purpose of the study is to analyse the structural differences of Silver fir with wave-grained wood compared with straight-grained wood (control). Forest types were determined by the forest-typological approaches proposed by Prof. Z.YU. Herushynskyy. The dating of annual rings was performed on LinTab equipment using the dendrochronological software TSAP. SPSS 13.0 software was used for statistical processing. The procedure for comparing mean values of annual rings was carried out using One-way ANOVA. The peculiarities of the formation of the annual growth of Silver fir with straight- and wavy-grained structural wood are studied. The differences of width of early and late wood on 40 model trees in six forest stands were considered. It is estimated that the average value of early wood width of Silver fir varied from 0.5 to $2.0 \mathrm{~mm}$. The significant increasing of the early wood width was due to local environmental factors. The average values of the late wood width in the straight-grained wood were characterized by lower figures than those with a wavy-grained structure. The average values of the annual ring width of straight-grained wood ranged from 2.36 to $3.53 \mathrm{~mm}$, and for trees with wavy-grained wood $-3.98-5.74 \mathrm{~mm}$. A significant difference $(\mathrm{p}<0.05)$ was found in the mean values of the annual ring width. The average width of the annual ring in the wavy-grained wood of Silver fir was equal $5.74 \mathrm{~mm}$, and the width of annual ring varied from 1.05 to $11.57 \mathrm{~mm}$. In four forest stands of Silver fir a statistically significant difference between the macrostructure of the straight- and wavy-grained wood was estimated by the one-way analysis of variance of the annual ring width. The significance between investigated trees with straight- and wavy-grained wood was equal $\mathrm{p}<0.05$, and a form of Silver fir "wave-grained" was proposed.

Keywords: silver fir; straight-grained wood; wave-grained wood; annual ring; early wood; late wood. 